\title{
STUDI PERBANDINGAN KEBIJAKAN INDUSTRI 4.0 INDONESIA DENGAN TIGA NEGARA LEADING GROUP FUTURE OF PRODUCTION
}

\section{COMPARATIVE STUDY OF INDONESIA'S INDUSTRY 4.0 POLICIES WITH THREE COUNTRIES OF LEADING GROUP OF FUTURE OF PRODUCTION}

Hari Wisnu Murti $\left.{ }^{\star}{ }^{\star}\right)$, M. Tirtana Siregar ${ }^{\left.2^{\star}\right)}$

1) Pusat Optimalisasi Pemanfaatan Teknologi Industri dan Kebijakan Jasa Industri, JI Jend gatot subroto kav 52-53, Jakarta. Indonesia 2) Program Studi Manajemen Logistik Industri Elektronika, Politeknik APP Jakarta

\section{Article history:

\author{
Keywords : \\ Policy \\ Industry \\ Indonesia
} \\ Industry 4.0 \\ Comparison}

ARTICLE INFORMATION

Received: November 20, 2020

Revised: March 12, 2021

Accepted: June 01, 2021

Keywords:

Kebijakan

Industri

Indonesia

Industri 4.0

Perbandingan
${ }^{*}$ Corresponding Author

Hari Wisnu Murti

Email : hariwisnumurti19@gmail.com

\section{A B S T R A C T}

The World Economic Forum has compiled a profile of future of production readiness among 100 countries in the world where Indonesia is in the nascent group and requires benchmarking to the leading groups through SWOT Analysis. This study aims to compare Indonesia's industry 4,0 policy with leading countries through a comparative study. The data is obtained from industry 4.0 policy from Indonesia and three leading countries. The results of the study indicate that the Making Indonesia 4.0 policy is on the right track to pursue manufacturing competence and answer future challenges that will be faced by Indonesia and the current baseline, has weaknesses in priority sectors that do not support increased complexity. Opportunities that can be taken are trade infrastructure with other countries, investment opportunities for countries that lack human resources, and cooperation in sustainability standards. The challenge lies in the common priority sectors of the industry and the absence of $\mathrm{Al}$ research priorities for health and biotechnology while Indonesia has a large domestic market.

\section{A B S T R A K}

World Economic Forum menyusun profil kesiapan industri masa depan pada 100 negara di dunia dimana Indonesia tergolong kelompok Nascent dan membutuhkan pembandingan dengan negara-negara kelompok Leading melalui analisa SWOT, Studi ini bertujuan untuk membandingkan kebijakan industri 4.0 Indonesia dengan negara-negara kelompok Leading melalui studi komparatif. Data diperoleh dari kebijakan industri 4.0 dari Indonesia dan tiga negara kelompok leading. Hasil dari studi mengindikasikan bahwa kebijakan Making Indonesia 4.0 telah pada jalur yang tepat untuk mengejar kompetensi manufaktur dan menjawab tantangan masa depan yang akan dihadapi Indonesia dan baseline saat ini, mempunyai kelemahan pada sektor prioritas yang tidak mendukung peningkatan kompleksitas. Peluang yang bisa diambil adalah infrastruktur perdagangan dengan negara lain, peluang investasi untuk negara yang kurang dalam sumber daya manusia, dan kerjasama standar sustainability. Tantangan ada pada kesamaan sektor prioritas industri dan belum adanya prioritas riset $\mathrm{Al}$ untuk kesehatan dan bioteknologi sementara Indonesia mempunyai pasar domestik yang besar.

\section{PENDAHULUAN}

Hadirnya isu industri 4.0 telah menjadi pusat perhatian masyarakat dunia terkait masa depan sistem produksi manufaktur baik oleh kalangan akademisi maupun kalangan praktisi industri [1] . 
Pengimplementasian teknologi industri 4.0 di perusahaan industri tidak hanya mengubah siklus produk, manajemen produksi, dan rantai pasok perusahaan industri, namun juga mengubah cara bekerja para pegawai dan budayanya serta hubungannya dalam ekosistem usaha secara nasional maupun global [2]. Negara atau pemerintah mengambil peran penting dalam rangka menciptakan ekosistem inovatif yang tepat dan mendorong perusahaan - perusahaan industri untuk dapat bertransformasi ke industri 4.0 [3]. Bagi sebuah negara, sangat penting untuk mendorong transformasi industri 4.0 di negaranya terlebih dalam rangka menjamin keberlanjutan rantai pasok logistik sebuah perusahaan industri dengan industri - industri selainnya karena hal ini akan memberikan dampak berkali lipat bagi pertumbuhan industri di negara tersebut [4].

Dalam rangka mendorong transformasi perusahaan - perusahaan industri di negara negara dunia pada era revolusi industri keempat, World Economic Forum telah menyusun profil kesiapan perindustrian masa depan di 100 negara dunia dan faktor - faktor yang mempengaruhi untuk memberikan gambaran kesiapan pemanfaatan peluang penumbuhan ekonomi terutama melalui kompetensi manufaktur di masa depan, memitigasi risiko dan tantangan, serta tangguh dan gesit dalam merespons guncangan di masa depan yang tidak diperkirakan. Kajian tersebut menilai seberapa baik kesiapan suatu negara saat ini untuk mendapatkan keuntungan dari perubahan sifat perindustrian di masa depan ditinjau dari kompetensi manufaktur saat ini dan tantangan yang akan dihadapi di masa depan. [5].

World Economic Forum menyusun komponen komponen yang dijadikan parameter acuan. Komponen - komponen ini dianggap sebagai faktor yang paling mempengaruhi kesiapan negara - negara dunia untuk bertransformasi di era revolusi industri keempat yang terdiri dari komponen-komponen drivers of production dan komponen-komponen structure of production. Komponen-komponen dalam drivers of production adalah demand environment, teknologi \& inovasi, kerangka institusional, perdagangan global dan investasi, sumber daya manusia, dan sustainable resources. Sementara komponen asesmen structure of production adalah skala dan kompleksitas [5].

Pada kajian tersebut, World Economic Forum mengklasifikasikan negara-negara dunia menjadi empat kelompok : 1) Kelompok Nascent yaitu negara - negara dengan kondisi basis perindustrian yang masih lemah dan menghadapi tantangan besar di masa depan; 2) Kelompok Legacy yaitu negara - negara dengan basis perindustrian yang masih lemah, namun tantangan yang harus dihadapi di masa depan relatif lebih ringan; 3) Kelompok High Potential yaitu negara negara yang mempunyai basis perindustrian yang kuat namun menghadapi tantangan besar di masa depan; dan 4) Kelompok Leading yaitu negara negara yang sudah mempunyai basis perindustrian yang kuat dengan tantangan yang relatif ringan di masa depan. [5]. Berdasarkan asesmen tersebut, Indonesia berada pada kelompok Nascent yang artinya Indonesia adalah negara dengan kondisi basis perindustrian yang masih lemah dan menghadapi tantangan besar di masa depan. Pada dasarnya pemerintah Indonesia berkomitmen untuk membangun industri manufaktur yang berdaya saing global melalui percepatan implementasi Industri 4.0. [6].

Merujuk pada Peraturan Pemerintah No 14 Tahun 2015 tentang Rencana Induk Pembangunan Industri Nasional, Indonesia bercita-cita menjadi negara industri yang tangguh. Hal tersebut tercermin dalam tujuan penyelenggaraan perindustrian oleh pemerintah adalah 1) mewujudkan industri nasional sebagai pilar dan penggerak perekonomian nasional; 2) mewujudkan kedalaman dan kekuatan struktur industri; 3) mewujudkan industri yang mandiri, berdaya saing, dan maju, serta Industri Hijau; 4) mewujudkan kepastian berusaha, persaingan yang sehat, serta mencegah pemusatan atau penguasaan industri oleh satu kelompok atau perseorangan yang merugikan masyarakat; 5) membuka kesempatan berusaha dan perluasan kesempatan kerja; 6) mewujudkan pemerataan pembangunan industri ke seluruh wilayah Indonesia guna memperkuat dan memperkukuh ketahanan nasional; dan 7) meningkatkan kemakmuran dan kesejahteraan masyarakat secara berkeadilan [7]. Berdasarkan amanat tersebut, maka tujuan perindustrian Indonesia seharusnya dapat membawa Indonesia ke kelompok Leading. Oleh karena itu, penulis bermaksud membandingkan kebijakan perindustrian di era industri 4.0 oleh pemerintah Indonesia dibandingkan dengan tiga negara yang termasuk kelompok Leading pada asesmen Future of Production World Economic Forum.

Studi perbandingan ini dianggap penting karena era revolusi industri 4.0 ini tidak hanya tergantung pada seberapa tepat kebijakan suatu negara diimplementasikan namun juga berkaitan dengan interaksi kebijakan suatu negara dengan negara lain [8]. Kajian pendahulu terkait Making Indonesia 4.0 menyatakan bahwa kebijakan kebijakan 
industri 4.0 yang dikeluarkan Indonesia tersebut diharapkan mampu mengakselerasi pertumbuhan ekonomi namun dapat memberikan dampak disruptif bagi aktivitas ekonomi nasional dan dunia [6]. Karena pada dasarnya era industri 4.0 sangat mempengaruhi pola kehidupan manusia,termasuk pada pola konsumsi, sosial, dan interaksi pada umumnya [9]. Kehadiran era revolusi industri 4.0 juga akan membuka peluang inovasi dan memacu pertumbuhannya secara cepat [10]. Bahkan karena pertumbuhannya diprediksi akan bersifat eksponensial, maka bagi negara - negara berkembang perlu untuk belajar dan mengambil contoh dari negara - negara maju [11]. Transformasi industri 4.0 sangat membutuhkan pembanding dan proyek percontohan karena dengannya dapat mempelajari perjalanan transformasi dan mengevaluasi sesuai kebutuhan dan tantangan yang dihadapi serta daya saing negara [12]. Daya saing suatu negara dapat dilihat dari beberapa parameter penilaian di antaranya adalah besar PDB dan kegiatan pangsa ekonomi dan industri menurut pendekatan teori daya saing porter [13] Karenanya, studi ini akan menjawab irisan berbagai urgensi yang ada untuk membandingkan kebijakan indonesia dalam bertransformasi di era industri 4.0 dengan negara - negara yang telah maju dalam industri 4.0 berdasarkan penilaian World Economic Forum berdasarkan kesamaan tingkat PDB dan intensitas aktivitas interaksi perdagangan ekspor-impor indonesia.

\section{METODE PENELITIAN}

Penelitian ini dilakukan melalui metode analisis deskriptif yang bersifat komparasi terhadap kebijakan industri 4.0 yang dilakukan di Indonesia dibandingkan dengan tiga negara yang ada pada kelompok Leading Group Future of Production berdasarkan hasil asesmen yang telah dilakukan oleh World Economic Forum. Tiga negara pembandingdipilih melalui ketentuan : 1) Termasuk Leading Group Future of Production; 2) Terdapat dua negara yang termasuk 10 negara dengan GDP terbesar di dunia pada tahun 2019. 3) Terdapat dua negara dengan transkaksi ekspor-impor terbesar dengan Indonesia. 4) Ketersediaan data Open Access di internet.

Data pada studi ini diperoleh dari dokumen kebijakan industri 4.0 oleh Indonesia dan negara pembanding. Selanjutnya, dilakukan studi perbandingan antara Making Indonesia 4.0 (MI 4.0) dibandingkan dengan kebijkan industri 4.0 di tiga negara pemanding untuk mendapatkan profil sebagai berikut : 1) Nama negara; 2) Visi perindustrian negara di era revolusi keempat; 3) Kondisi yang dialami negara saat diterbitkannya kebijakan; 4) Langkah - langkah strategis; 5) Sektor penerapan; dan 6) Target capaian.

Hasil dari studi ini diharapkan akan memberikan gambaran perbandingan kebijakan industri 4.0 Indonesia dengan negara - negara leading group pada asesmen Future of Production World Economic Forum yang berada pada 10 besar GDP dunia dan yang tidak serta yang aktif dalam transaksi impor indonesia dengan yang tidak pada profil langkah - langkah strategis yang diambil, area penerapan, dan target capaian. Secara ringas, algoritma metode penelitian digambarkan melalui diagram alir gambar 1.

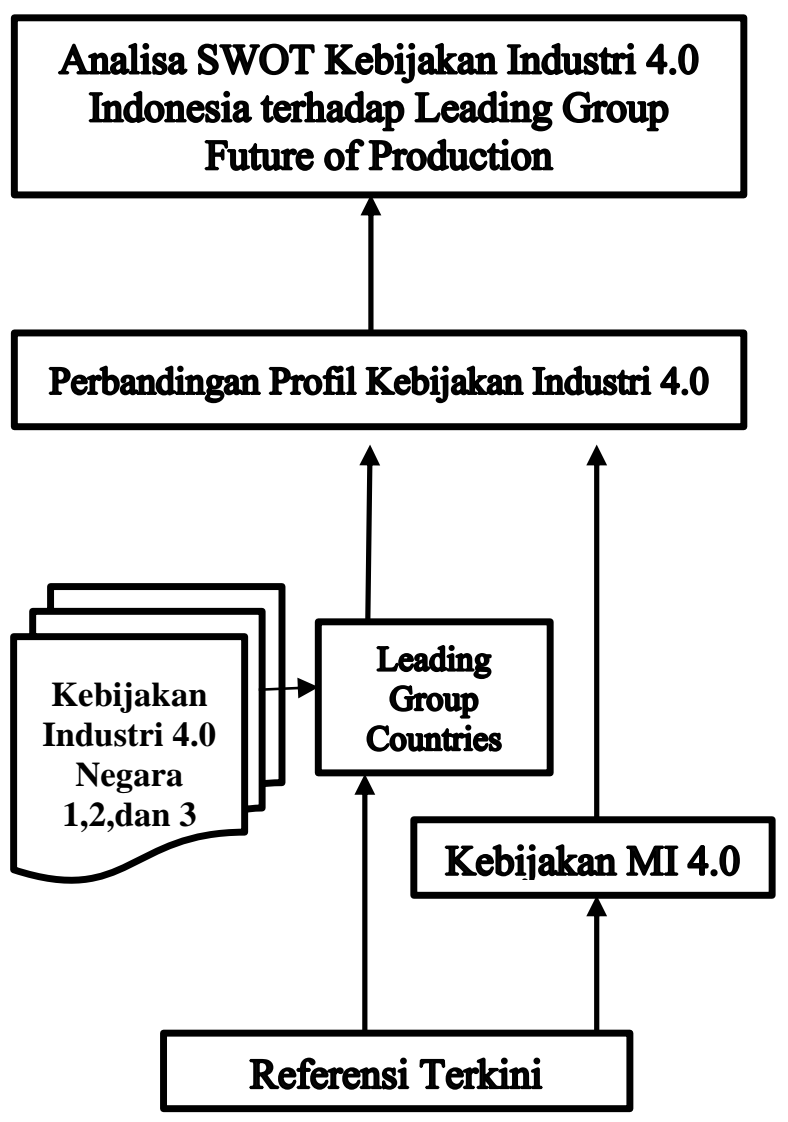

Gambar 1. Pola pikir kajian perbandingan profil kebijakan industri 4.0

\section{HASIL DAN PEMBAHASAN}

Dalam rangka mendorong transformasi negara negara dunia di era revolusi industri keempat, World Economic Forum telah menyusun profil kesiapan perindustrian masa depan di 100 negara dunia dan faktor - faktor apa yag mempengaruhi untuk memberikan gambaran kesiapan pemanfaatan peluang penumbuhan ekonomi 
terutama melalui sektor perindustrian di masa depan, memitigasi risiko dan tantangan, serta tangguh dan gesit dalam merespons guncangan di masa depan yang tidak diperkirakan. Dasar asesmen kemampuan perindustrian suatu negara di masa depan oleh World Economic Forum tersebut disusun berdasarkan komponen komponen parameter acuan yang dianggap sebagai faktor yang paling mempengaruhi kesiapan negara - negara dunia untuk bertransformasi di era revolusi industri keempat. Komponen-komponen dalam drivers of production adalah demand environment, teknologi \& inovasi, kerangka institusional, perdagangan global dan investasi, sumber daya manusia, dan sustainable resources. Sementara komponen - komponen untuk structure of production adalah skala dan kompleksitas. [3].

Terdapat 25 negara yang termasuk kelompok Leading Group yang terdiri dari Austria, Belgia, Canada, Tiongkok, Republik Ceko, Denmark, Estonia, Finlandia, Prancis, Jerman, Irlandia, Israel, Italia, Jepang, Korea, Malaysia, Belanda, Polandia, Singapura, Slovenia, Spanyol, Swedia, Swiss, Inggris, dan Amerika Sertikat [3]. Dari 25 negara tersebut kami pilih tiga negara pembanding berdasarkan ketentuan : 1) Terdapat dua negara termasuk 10 besar GDP dunia dan satu negara di luar itu. Indonesia berada di peringkat 16 GDP dunia tahun 2019 sementara 10 Besar Negara GDP Terbesar di dunia adalah Amerika Serikat, Tiongkok, Jepang, Jerman, India, Inggris, Prancis, Italia, Brazil, dan Canada [14]; 2) Terdapat dua negara yang termasuk 10 besar negara dengan jumlah transaksi impor dan satu tidak termasuk. Sepuluh besar asal negara transaksi impor indonesia adalah Tiongkok, Singapura, Jepang, Thailand, Amerika Serikat, Korea Selatan, Malaysia, Australia, India, dan Vietnam [15]. Secara ringkas, disampaikan negara-negara yang tergabung dalam kedua himpunan 10 besar PDB dan asal negara transaksi impor pada tabel 1.

Tabel 1. Ringkasan Negara 10 Besar PDB dan Asal Negara Transaksi Impor

\begin{tabular}{lll}
\hline No & $\begin{array}{l}\text { Negara } \\
\text { Besar PDB }\end{array}$ & $\begin{array}{l}\text { Asal } \\
\text { Transaksi Impor }\end{array}$ \\
\hline 1 & Amerika Serikat & Tiongkok \\
2 & Tiongkok & Singapura \\
3 & Jepang & Jepang \\
4 & Jerman & Thailand \\
5 & India & Amerika Serikat \\
6 & Inggris & Korea Selatan \\
7 & Prancis & Malaysia \\
8 & Italia & Australia
\end{tabular}

\begin{tabular}{lll}
9 & Brazil & India \\
10 & Canada & Vietnam \\
\hline
\end{tabular}

Dari hasil pemerian anggota himpunan negaranegara 10 besar PDB dunia dan negara-negara 10 besar asal impor, kemudian dilakukan perbandingan dengan negara-negara kelompok Leading Group. Selanjutnya dilakukan identifikasi anggota himpunan sebagaimana yang dijelaskan pada tabel 2. Hal ini dirasa perlu karena kebijakan industri yang akan diimplementasikan di era indutri 4.0 sangat berpengaruh pada capaian PDB Nasional dan aktivitas perdagangan masingmasing negara [16].

Hasil dari studi ini diharapkan akan memberikan gambaran perbandingan kebijakan industri 4.0 Indonesia dengan negara - negara leading group pada asesmen Future of Production World Economic Forum yang berada pada 10 besar GDP dunia dan yang tidak serta yang aktif dalam transaksi impor indonesia dengan yang tidak pada profil langkah - langkah strategis yang diambil, area penerapan, dan target capaian.

Tabel 2. Ringkasan Negara Leading Group 10 Besar PDB dan Asal Negara Transaksi Impor

\begin{tabular}{llll}
\hline $\begin{array}{l}\text { Negara } \\
\text { Kelompok } \\
\text { Leading } \\
\text { Group }\end{array}$ & $\begin{array}{l}\text { 10 } \\
\text { Besar PDB }\end{array}$ & $\begin{array}{l}\text { 10 Asal Negara } \\
\text { Transaksi Impor }\end{array}$ \\
\hline AUS & & \\
BEL & & & \\
CAN & & $\sqrt{ }$ & \\
RRC & & $\sqrt{ }$ & $\checkmark$ \\
RCE & & & \\
DEN & & & \\
EST & & \\
FIN & & \\
FRA & $\sqrt{ }$ & \\
GER & & $\sqrt{ }$ \\
IRL & & & \\
ISR & & $\sqrt{ }$ \\
ITA & & $\sqrt{ }$ \\
JAP & & \\
KOR & & $\sqrt{ }$ \\
MAY & & \\
NET & & \\
POL & & \\
SIN & & \\
SLO & & \\
SPA & & \\
SWE & & \\
SWI & & \\
UK & & \\
AS & & \\
\hline
\end{tabular}


Selanjutnya dilakukan pencarian terhadap kebijakan industri 4.0 di internet dari dua negara yang termasuk 10 besar PDB dunia dan satu negara di luar itu serta dua negara 10 negara asal impor terbesar dan satu negara di luar itu dari tabel 2. Selanjutnya dipilih negara Leading Group sebagai pembanding kebijakanadalah Malaysia, Inggris, dan Jepang sebagaimana dijelaskan pada tabel 3.

Tabel 3. Ringkasan Hasil Pencarian Ketersedian Data Dokumen Kebijakan di Internet dari negara negara Leading Group dengan kriteria

\begin{tabular}{|c|c|c|c|}
\hline $\begin{array}{l}\text { Negara } \\
\text { Kelompok } \\
\text { Leading } \\
\text { Group }\end{array}$ & $\begin{array}{l}10 \\
\text { Negara } \\
\text { Besar } \\
\text { PDB }\end{array}$ & $\begin{array}{l}10 \text { Asal } \\
\text { Negara } \\
\text { Transaksi } \\
\text { Impor }\end{array}$ & $\begin{array}{l}\text { Tersedia } \\
\text { Data } \\
\text { Dokumen } \\
\text { Kebijakan }\end{array}$ \\
\hline MAY & & $\sqrt{ }$ & $\sqrt{ }$ \\
\hline UK & $\sqrt{ }$ & & $\sqrt{ }$ \\
\hline JAP & $\sqrt{ }$ & $\sqrt{ }$ & $\sqrt{ }$ \\
\hline
\end{tabular}

Analisis selanjutnya adalah studi terhadap dokumen-dokumen-dokumen kebijakan dari
Indonesia, Malaysia, Inggris, dan Jepang sehingga didapatkan hasil sebagai berikut :

\subsection{Indonesia}

Berdasarkan dokumen Future of Production yang diterbitkan oleh World Economic Forum, Indonesia berada di kelompok nascent dengan nilai sebagaimana disebutkan pada gambar 2

Sementara itu, sebagai negara nascent, Indonesia harus melewati nilai ambang batas untuk berpindah dari grup nascent. Nilai yang dijadikan ambang batas kelompok nascent berpindah menuju legacy adalah 5,8 pada structure of production dan untuk berpindah ke high potential adalah 5,8 pada driver of production sementara untuk menjadi kelompok leading harus mencapai pada 5,8 pada kedua aspek penilaian.Sehingga pada kondisi baseline ini Indonesia hanya mempunyai keunggulan skala pasar dan masih lemah pada tujuh komponen lainnya.

\section{Indonesia}

Readiness for the Future of Production Assessment 2018 edition

\begin{tabular}{|c|c|c|c|}
\hline \multicolumn{4}{|l|}{ Key economic indicators } \\
\hline Population makons & 258.7 & GDP per capita USs & $3,604.3$ \\
\hline GDP uss baliona & 932.4 & Unemployment rate : & 5.6 \\
\hline \multicolumn{4}{|l|}{ Key production indicators } \\
\hline Manufacturing value added 2010 milions USs & $225,673.8$ & Manufacturing value added growth Amual s & 5.6 \\
\hline Manufacturing value added in economy $\leqslant \triangle D P$ & 21.8 & Medium hi-tech \& hi-tech industries s of manu wene added & 35.1 \\
\hline Manufacturing employment $\leqslant$ woning population & 13.5 & CO2 emission per unit of value added logusD & 0.4 \\
\hline
\end{tabular}

Readiness Overall Assessment

\begin{tabular}{|c|c|c|c|}
\hline \multicolumn{3}{|c|}{ Drivers of Production } & \multirow{2}{*}{$\begin{array}{r}4.9 \\
\text { Soone } \mathrm{nt}\end{array}$} \\
\hline Driver & Woighting & Fank & \\
\hline $\begin{array}{l}\text { Technology s } \\
\text { Innowation }\end{array}$ & $20 \%$ & 61st & 4.0 \\
\hline $\begin{array}{l}\text { Human } \\
\text { Capital }\end{array}$ & $20 \%$ & 55 en & 5.0 \\
\hline $\begin{array}{l}\text { Global Trade } \\
\text { A Investimemt }\end{array}$ & $20 \%$ & 61st & 5.1 \\
\hline $\begin{array}{l}\text { Institunional } \\
\text { Framework }\end{array}$ & $20 \%$ & egen & 4.6 \\
\hline $\begin{array}{l}\text { Sustainable } \\
\text { Pesources }\end{array}$ & $5 \%$ & 945 & 4.1 \\
\hline $\begin{array}{l}\text { Demand } \\
\text { Environment }\end{array}$ & $15 \%$ & 15 en & 6.4 \\
\hline Structure of Pro & duction & & 5.4 \\
\hline Structure & Woighsing & Fark & Socre fid \\
\hline Complexity & $60 \%$ & 73rd & 4.3 \\
\hline Scale & $40 \% \%$ & ent & 7.1 \\
\hline
\end{tabular}

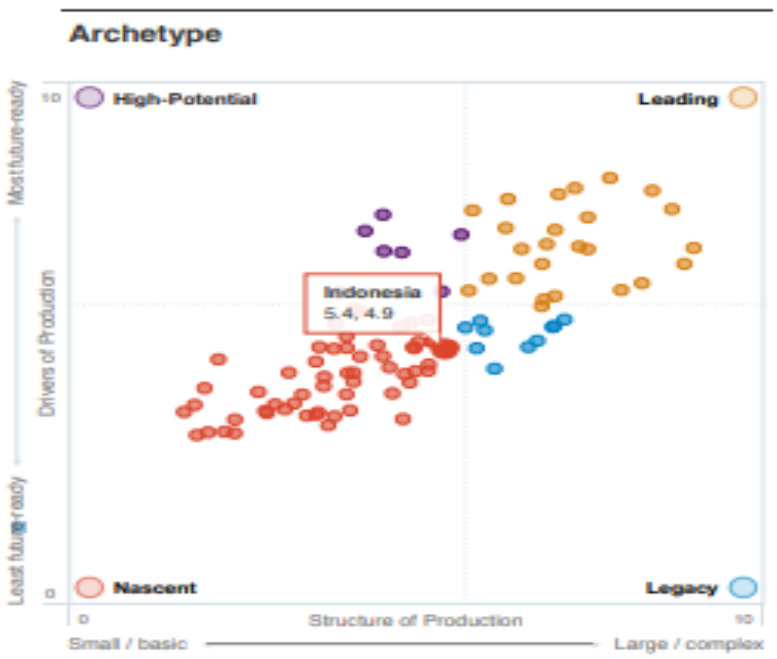

Gambar 2 Laporan Nilai Indonesia dalam Asesmen Future of Production [5] 
Melalui strtegi kebijakan Industri 4.0, Indonesia telah meluncurkan peta jalan Making Indonesia 4.0 dengan visi : (1) Menggandakan rasio produktivitas terhadap biaya produksi; (2) Mendorong Ekspor Netto menjadi bagian 10\% PDB; dan (3) Menganggar 2\% dari PDB untuk ekosistem inovasi penelitian dan pengembangan.

Kondisi yang telah dialami Indonesia adalah tengah pada pembangunan ekonomi yang baik dan dihadapkan pada tantangan puncak bonus demografi pada tahun 2030. Langkah strategis yang ditempuh adalah : (1) Perbaikan alur aliran barang dan material; (2) Desain ulang zona industri; (3) Mengakomodasi standar-standar sustainability; (4) Memberdayakan UKM; (5) Membangun infrastruktur digital nasional; (6) Menarik minat investasi asing; (7) Peningkatan kualitas sumber daya manusia; (8) Pembangunan ekosistem inovasi; (9) Insentifuntuk investasi teknologi; dan (10) Harmonisasi aturan dan kebijakan.

Sektor penerapan yang akan diimplementasikan adalah lima sektor prioritas yang dipilih berdasarkan asesmen kemudahan implementasi teknologi industri 4.0 dan nilai dampaknya terhadap pertumbuhan nasional yaitu: (1) industri makanan dan minuman, (2) industri tekstil dan produk tekstil, (3) industri elektronika, (4) industri otomotif, dan (5) industri kimia. Memasuki pandemi Covid-19, Pemerintah Republik Indonesia menambahkan sektor prioritas (6) Farmasi, dan (7) alat kesehatan untuk penerapan industri 4.0

Target capaian yang ingin diwujudkan adalah (1) pertumbuhan PDB di angka 6-7\% pada baseline 2018-2030; (2) Menciptakan lebih dari 30 juta lapangan kerja di tahun 2030; (3) Menempatkan lebih dari $25 \%$ kontribusi sektor manufaktur pada PDB hingga 2030 [17].

\subsection{Malaysia}

Malaysia dalam hasil asesmen Future of Production menunjukkan hasil asesmen sebagai mana disampaikan pada gambar 3.

Dari data tersebut terlihat bahwa Malaysia mempunyai keunggulan dalam bidang Global Trade and investment yaitu perdagangan. Dengan strategi kebijakan industri 4.0 nya, Malaysia telah meluncurkan dokumen Industry 4WRD Malaysia dengan visi : (1) Meningkatkan kontribusi sektor manufaktur terhadap PDB; (2) Meningkatkan nilai tambah produk manufaktur; dan (3) Menjamin Kontinuitas investasi Global. Kondisi di malaysia saat diterbitkannya kebijakan ini adalah sektor manufaktur menjadi sektor penyerap tenaga kerja terbesar kedua setelah sektor jasa mengingat Malaysia adalah negara perdagangan.

Langkah strategis yang ditempuh adalah : (1) Pendanaan dan Insentif berbasis Outcome; (2) Menjalankan ekosisten dan memanfaatkan infrastruktur digital; (3) Kerangka kerja regulasi dan adopsi kapasitas industri; (4) Peningkatan Keterampilan Sumber Daya Manusia; dan (5) Pemanfaatan dan Pengembangan Teknologi Secara Masif. Fokus sektor penerapan industri 4.0 pada : (1) Sektor elektronik dan kelistrikan; (2) Permesinan dan Peralatan; (3) Kimia; (4) Peralatan Kesehatan; (5) Dirgantara.

Pemerintah Malaysia menentukan adanya empat capaian nasional yang akan dicapai pada tahun 2025 dari kebijakan nasional Malaysia 4WRD yaitu : (1) Meningkatkan level produktivitas sektor manufaktur dengan pertumbuhan $30 \%$; (2) Meningkatkan kontribusi sektor manufaktur terhadap pertumbuhan ekonomi dari 254 juta ringgit malaysia di tahun 2016 menjadi 394 juta ringgit malaysia di tahun 2025; (3) Memperkuat kapasitas dan kapabilitas inovasi yang unggul di tingkat global menembus 30 besar Global Innovation Index Ranking; (4) Meningkatkan jumlah tenaga kerja terampil di sektor manufaktur dari $18 \%$ tenaga kerja terampil di tahun 2016 menjadi 35\% di tahun 2025. [18]

\subsection{Inggris}

Berdasarkan hasil asesmen Future of Production disampaikan baseline kondisi Inggris sebagaimana pada gambar 4.

Berdasarkan asesmen tersebut, Inggris mempunyai kelemahan pada skala pasar yang domestik yang dimiliki. Melalui kebijakan industri 4.0 nya, Inggris menerbitkan dokumen Industrial Strategy Building a Britain Fit for The Future. Visi perindustrian di era revolusi industri 4.0 adalah (1) Menjadi negara dengan perekonomian berbasis inovasi; (2) Membuka lapangan pekerjaan yang luas dengan pendapatan yang besar; (3) Membangun infrastruktur lebih baik; (4) Menjadi negara yang bagus untuk memulai dan menumbuhkan bisnis; (5) Menjadi negara yang makmur. Kondisi yang tengah dialami Inggris saat itu adalah sebagai negara yang banyak menginvestasikan pada sektor inovasi teknologi dan komersialisasinya selain terus membangun ekonomi dan industri yang kompetitif. 


\section{Malaysia}

Readiness for the Future of Production Assessment 2018 edition

\section{Key economic indicators}

\begin{tabular}{|c|c|c|c|}
\hline Population malions & 31.7 & GDP per capita uss & $9,360.5$ \\
\hline GDP uss biliona & 296.4 & Unemployment rate : & 3.5 \\
\hline \multicolumn{4}{|l|}{ Key production indicators } \\
\hline Manufacturing value added 2010 milions USS & $79,820.6$ & Manufacturing value added growth Amual s & 3.9 \\
\hline Manufacturing value added in economy $\$$ GDP & 23.9 & Medium hi-tech \& hi-tech industries s of manu value added & 42.6 \\
\hline Manufacturing employment ss woning population & 16.5 & CO2 emission per unit of value added kg/usD & 0.4 \\
\hline
\end{tabular}

\section{Readiness Overall Assessment}

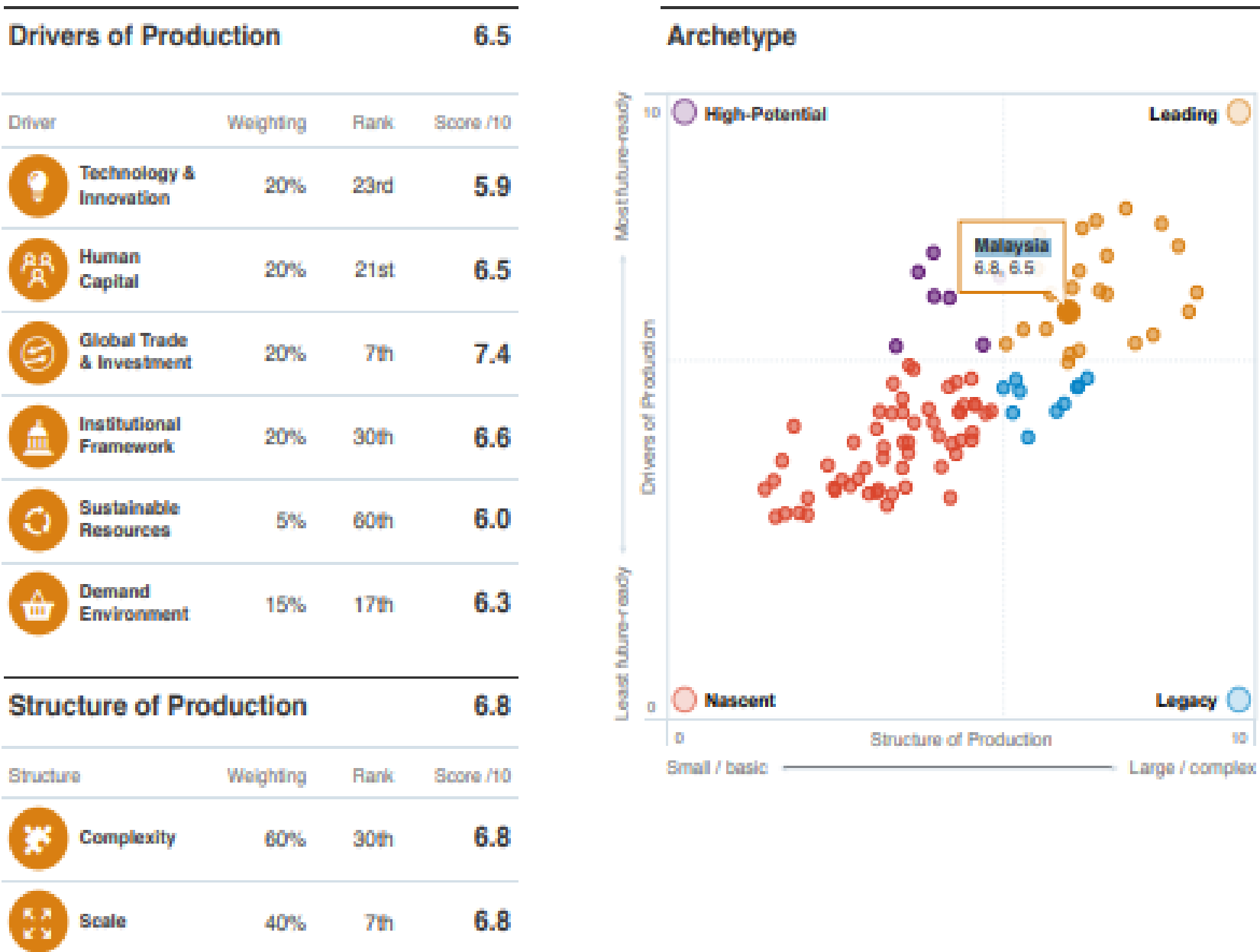

Gambar 3 Laporan Nilai Malaysia dalam Asesmen Future of Production [5] 


\section{United Kingdom}

Readiness for the Future of Production Assessment 2018 edition

\begin{tabular}{|c|c|c|c|}
\hline Population malions & 65.6 & GDP per capita USs & $40,095.9$ \\
\hline GDP uss biliona & $2,629.2$ & Unemployment rate $\$$ & 4.9 \\
\hline \multicolumn{4}{|l|}{ Key production indicators } \\
\hline Manufacturing value added 2010 millons USs & $228,271.1$ & Manufacturing value added growth Amual s & -0.4 \\
\hline Manufacturing value added in economy $\leqslant G D P$ & 8.3 & Medium hi-tech \& hi-tech industries $\leqslant$ of manu wise added & 47.4 \\
\hline Manufacturing employment ss wonking population & 9.6 & CO2 emission per unit of value added lighusD & 0.2 \\
\hline
\end{tabular}

Readiness Overall Assessment

\begin{tabular}{|c|c|c|c|c|}
\hline \multicolumn{4}{|c|}{ Drivers of Production } & \multirow{2}{*}{$\begin{array}{r}7.8 \\
\text { Soore } / 10\end{array}$} \\
\hline Driver & & Weighing & Fark & \\
\hline & $\begin{array}{l}\text { Technology s } \\
\text { Innovation }\end{array}$ & $20 \%$ & 2nd & 8.0 \\
\hline & $\begin{array}{l}\text { Human } \\
\text { Capital }\end{array}$ & $20 \%$ & 8 th & 7.5 \\
\hline & $\begin{array}{l}\text { Clobal Trade } \\
\text { A Investment }\end{array}$ & $20 \%$ & 4 th & 8.3 \\
\hline & $\begin{array}{l}\text { Institulional } \\
\text { Framework }\end{array}$ & $20 \%$ & 13th & 8.2 \\
\hline & $\begin{array}{l}\text { Sustainable } \\
\text { Resources }\end{array}$ & $5 \%$ & 22 nd & 7.4 \\
\hline & $\begin{array}{l}\text { Demand } \\
\text { Environment }\end{array}$ & $15 \%$ & 6th & 7.1 \\
\hline \multicolumn{3}{|c|}{ Structure of Production } & & 7.0 \\
\hline \multicolumn{2}{|c|}{ Structure } & Woighing & Fank & Soore $/ 10$ \\
\hline & Complexity & $60 \%$ & 8 sh & 8.6 \\
\hline & Scale & $40 \%$ & $37 t h$ & 4.7 \\
\hline
\end{tabular}

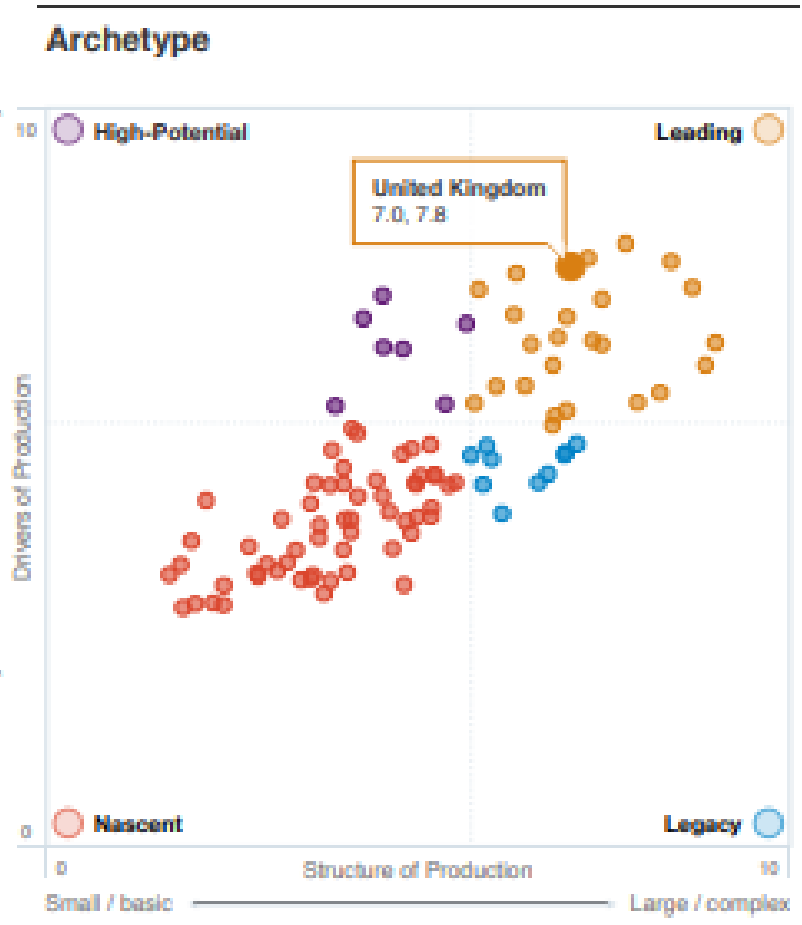

Gambar 4 Laporan Nilai Inggris dalam Asesmen Future of Production [5]

Langkah Strategis yang ditempuh adalah (1) Memperkuat pondasi produktivitas; (2) Membangun kerjasama jangka panjang dengan pihak - pihak terkait; (3) Mengambil tantangan besar di masa depan yang menjadi komitmen arah pembangunan inovasi industri dan peradaban.

Area penerapan yang akan dilaksanakan yaitu di bidang : (1) Artificial Intelligence dan Data. Inggris akan menjadi pemenang di teknologi Al dan revolusi data. Misi utama yang dijalankan adalah pemanfaatan data, $\mathrm{Al}$, dan inovasi dalam rangka transformasi di bidang pencegahan penyakit, diagnosism dan pengobatan penyakit kronis di tahun 2030; (2) Pertumbuhan industri yang ramah lingkungan; (3) Akselerator mobilitas barang dan manusia, menciptakan kendaraan tanpa emisi di tahun 2040; (4) Layanan penuaan masyarakat 


\section{Japan}

Readiness for the Future of Production Assessment 2018 edition

\begin{tabular}{|c|c|c|c|}
\hline \multicolumn{4}{|l|}{ Key economic indicators } \\
\hline Population malions & 126.9 & GDP per capita USs & $39,917.3$ \\
\hline GDP uss biliona & $4,938.6$ & Unemployment rate : & 3.1 \\
\hline \multicolumn{4}{|l|}{ Key production indicators } \\
\hline Manufacturing value added 2010 milions Uss & $1,075,547.5$ & Manufacturing value added growth Amual s & 0.0 \\
\hline Manufacturing value added in economy $\$ Q D P$ & 18.8 & Medium hi-tech \& hi-tech industries $\leqslant$ of manu vilue added & 55.3 \\
\hline Manufacturing employment $\leqslant$ woning pepulation & 16.2 & CO2 emission per unit of value added hy usD & 0.2 \\
\hline
\end{tabular}

Readiness Overall Assessment

\begin{tabular}{ll}
\hline Drivers of Production & 6.8
\end{tabular}

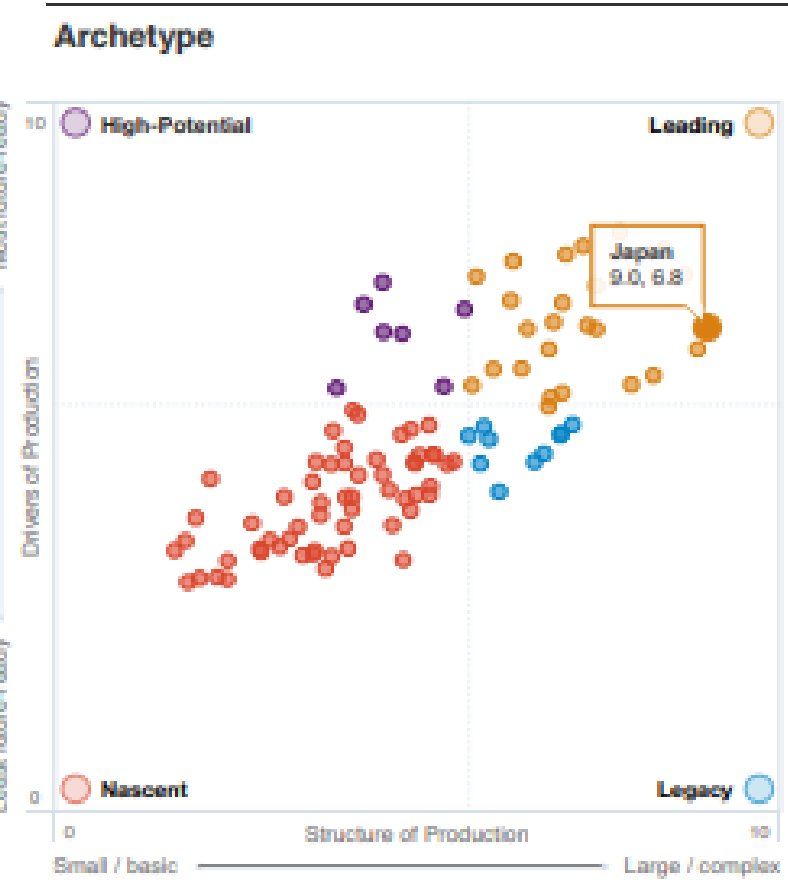

\begin{tabular}{|c|c|c|c|}
\hline \multicolumn{2}{|c|}{ Structure of Production } & & \multirow{2}{*}{$\begin{array}{r}9.0 \\
\text { Scone } / 10\end{array}$} \\
\hline Sructure & Weighting & Fank & \\
\hline Complexity & $60 \%$ & 1st & 10.0 \\
\hline Scale & $40 \%$ & 5 th & 7.5 \\
\hline
\end{tabular}

Gambar 5. Laporan Nilai Jepang dalam asesmen Future of Production[5]

dimana inovasi dapat memberikan pelayanan sebagai antisipasi dampak semakin tingginya angka harapan hidup di luar masa produktif. Capaian yang diharapkan pada tahun 2030 adalah berhasil menjadi negara dengan perekonomian paling maju berbasis inovasi. Menginvestasikan 2,6 milyar pounds per tahun hingga tahun 2020 untuk pendidikan programmer Pemanfaatan Al dan inovasi dalam rangka transformasi di bidang pencegahan penyakit, diagnosism dan pengobatan penyakit kronis di tahun 2030 dan menciptakan kendaraan tanpa emisi di tahun 2040 [19].

\subsection{Jepang}

Berdasarkan hasil asesmen Future of Production disampaikan baseline kondisi Jepang sebagaimana disebutkan pada gambar 5 . 
Jepang mempunyai kelemahan dalam ketersediaan sumber daya manusia industri dan pasar. Jepang menerbitkan New Industrial Structure Vision yang bervisi masyarakat berperadaban integrasi teknologi atau yang dikenal Society 5.0. Kondisi yang tengah dialami jepang saat itu adalah tengah menghadapi tantangan anti klimaks pertumbuhan ekonomi makro nasional dan tantangan struktur masyarakat pasca bonus demografi.

Langkah strategis yang ingin ditempuh diantaranya : (1) Mengembangkan Teknologi Mobil Otomatis; (2) Mengembangkan Drone; (3).Mengembangkan Full Scale manufaktur berbasis teknologi informasi dan data serta konektivitas; (4) Menjadi Pusat Robot, Sensor, dan Artificial Intelligence; (5) Mengembangkan teknologi yang disebut Personal Health Record yang merupakan teknologi yang memungkinkan individu untuk memanajeen data perawatan kesehatan, medis, dan keperawatan mereka dari waktu ke waktu; (6)Mengembangkan Fin Tech; (7) Mengembangkan IKM.

Sektor yang akan diterapkan antara lain : (1) Sektor mobilitas; (2) Supply chain; (3) Layanan kesehatan; (4) Dinamika gaya hidup. Target capaian yang ditetapkan adalah Pemerintah Jepang bercita-cita mewujudkan peradaban masyarakat Society 5.0 yang mengkoneksikan antara mesin dan manusia serta mesin dengan sesama mesin melalui kehadiran teknologi di era industri keempat ini. [20]. Ringkasan dari uraian kebijakan keempat negara dapat dilihat di tabel 4.

Melalui uruaian deskripsi kebijakan yang disebutkan di atas, dilakukan analisa Kekuatan dan Kelemahan kebijakan yang dikeluarkan indonesia terhadap kondisi baseline yang dihadapi serta peluang dan tantangan dibandingkan dengan baseline dan kebijakan negara-negara lain :

Kekuatan :

1. Mendukung peningkatan nilai komponen Technology and Innovation dan Human capital melalui program peningkatan kualitas sumber daya manusia dan membentuk ekosistem inovasi sesuai visi peningkatan produktivitas. Peningkatan teknologi juga akan berdampak pada nilai kompleksitas sehingga semakin banyak varian produk yang dapat dihasilkan

2. Meningkatkan nilai institutional framework melalui langkah harmonisasi kebijakan

3. Meningkatkan nilai sustainable resources melalui pemenuhan standar-standar sustainability
Kelemahan :

1. Sektor prioritas yang dipilih tidak mendorong keunggulan nilai kompleksitas karena tidak membuka kebaruan produk melainkan mengikuti produk manufaktur yang sedang dan sudah berjalan

Peluang :

1. Melalui langkah strategis memperbaiki aliran barang dan material, Indonesia bisa mengambil manfaat dari kebijakan peningkatan infrastruktur digital Malaysia dan Jepang untuk menjamin pemenuhan aliran rantai pasok bahan baku atau bahan penolong industri domestik

2. Indonesia mempunyai peluang untuk menarik investasi jepang membangun industri manufaktur sektor-sektor prioritas melihat langkah strategi prioritas Indonesia diantaranya adalah menarik investasi asing dan jepang berada pada baseline kekurangan sumber daya manusia.

3. Indonesia mempunyai peluang kerjasama dengan Inggris untuk mendukung akomodasi standar-standar sustainability

Tantangan :

1. Malaysia sebagai salah satu negara yang paling banyak melakukan transaksi ekspor impor di Indonesia bermaksud mereindustrialisasi negaranya dari negara perdagangan ke negara industri, hal ini tentu akan menjadi tantangan bagi pasar domestik Indonesia terutama pada komoditas prioritas yang sama yaitu kimia dan elektronika.

2. Inggris memproritaskan riset Aritificial Intelligence dan bioteknologi untuk meraih keunggulan kompetitif pada industri kesehatan. Indonesia belum memfokuskan penerapan kebijakan industri 4.0 pada kombinasi pemanfaatan bioteknologi dan Artificial intelligence untuk menunjang produksi alat kesehatan yang maju sementara pasar domestik Indonesia besar sementara Indonesia mempunyai skala pasar yang besar untuk jumlah penduduk yang tentu akan memunculkan permintaan terhadap alat kesehatan yang maju.

3. Jepang memprioritaskan riset Artificial Intelligence dan kesehatan dalam implementasi kebijakan industri 4.0 serta mengembangkan mesin-mesin dan kendaraan cerdas dimana kondisi Indonesia belum menempatkan prioritas Artificial Intelligence dan kesehatan untuk memenuhi kebutuhan pasar domestiknya dan harus bersaing dalam sektor industri otomotif yang juga menjadi sektor prioritas jepang. 
Tabel 4. Ringkasan Kebijakan Empat Negara

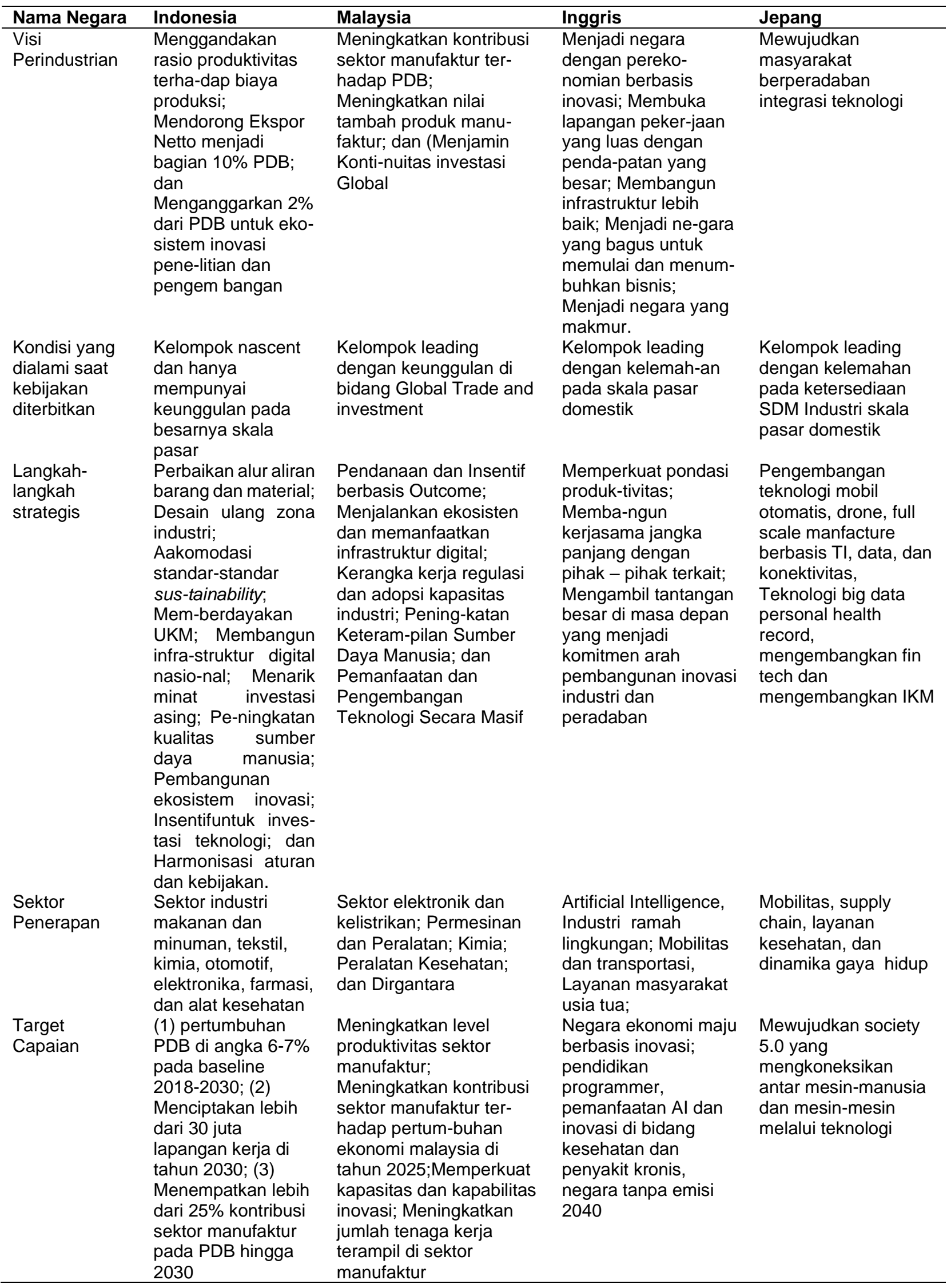




\section{KESIMPULAN}

Kesimpulan pada studi ini adalah keempat negara menerbitkan kebijakan masing-masing berjudul Making Indonesia 4.0 oleh Indonesia, Industry 4WRD Malaysia oleh Malaysia, Industrial Strategy Building a Britain Fit for The Future oleh Inggris, dan New Industrial Structure Vision oleh Jepang.

Indonesia dan Malaysia yang saat ini berada di luar 10 besar PDB dunia mempunyai fokus pencapaian peningkatan PDB dan penguatan kontribusi sektor manufaktur terhadap PDB sementara untuk Inggris dan Jepang yang telah berada pada 10 besar PDB dunia mempunyai fokus pencapaian berupa pengembangan teknologi maju yang dapat diterapkan pada kehidupan masyarakat dan komersial.

Langkah-langkah strategis yang ingin diterapkan masing-masing negara memiliki persamaan dan perbedaan. Hal tersebut tentunya sangat bergantung pada kondisi yang tengah dialami negara saat diterbitkannya kebijakan, posisi negara dalam ekonomi dunia serta transaksinya pada pasar internasional, dan tantangan yang akan dialami oleh masing-masing negara di masa depan.

Pada dasarnya kebutuhan Indonesia untuk mengejar kompetensi sektor manufaktur pada baseline saat ini dibandingkan dengan negaranegara Leading Group pada asesmen Future of Production relatif besar, sehingga diperlukan kebijakan yang berorientasi pada peningkatan kompetensi manufaktur saat ini dan menjawab tantangan masa depan. Kebijakan Making Indonesia 4.0 telah On The Track untuk meningkatkan kompetensi manufaktur Indonesia dan menyiapkan tantangan masa depan indonesia berupa bonus demografi pada tahun 2030 melalui peningkatan pertumbuhan PDB dan penciptaan lapangan kerja melalui sektor industri manufaktur.

Adanya perbedaan visi, area penerapan, langkah strategi, dan target capaian antara kebijakan industri indonesia dengan negara leading group lain bukan berarti salah, namun dikarenakan masing-masing negara saat ini berada baseline yang berbeda dan akan menghadapi tantangan yang berbeda di masa depan.

Dari pembahasan kebijakan industri 4.0 Indonesia dan tiga negara lain kebijakan industri 4.0 dinilai dapat meningkatkan nilai asesmen indonesia terutama pada komponen Technology and innovation, human capital, kompleksitas, institutional framework, dan sustainable resources. Kelemahannya adalah sektor prioritas tidak mendorong peningkatan nilai kompleksitas. Peluang dari kebijakan industri 4.0 Indonesia dengan kebijakan industri 4.0 negara lain adalah prioritas memperbaiki aliran barang dan material disertai kebijakan negara lain meningkatkan infrastruktur digital akan membantu Indonesia mendapatkan kemudahan bahan baku/bahan penolong produksi, menarik investasi dan menyediakan sumber daya industri untuk negaranegara dengan baseline kekurangan sumber daya manusia, dan peluang kerjasama membangun kerjasama akomodasi standar sustainability. Tantangan yang harus dihadapi adalah kesamaan produk prioritas dengan malaysia pada sektor kimia dan elektronika. Terhadap Inggris dan Jepang, Kebijakan Indonesia belum menjangkau prioritas riset $\mathrm{Al}$ dan kesehatan serta bioteknologi sementara Indonesia mempunya baseline pasar domestik yang besar.

\section{REFERENSI}

[1] Y. Liao, F. Deschamps, E. de F. R. Loures, and L. F. P. Ramos, "Past, present and future of Industry 4.0 - a systematic literature review and research agenda proposal," International Journal of Production Research. 2017, doi: 10.1080/00207543.2017.1308576.

[2] W. Bauer, M. Hämmerle, S. Schlund, and C. Vocke, "Transforming to a Hyperconnected Society and Economy Towards an 'Industry 4.0,"' Procedia Manuf., 2015, doi: 10.1016/j.promfg.2015.07.200.

[3] R. Morrar and H. Arman, "The Fourth Industrial Revolution (Industry 4.0): A Social Innovation Perspective," Technol. Innov. Manag. Rev., 2017, doi: 10.22215/timreview/1117.

[4] E. Hofmann and M. Rüsch, "Industry 4.0 and the current status as well as future prospects on logistics," Comput. Ind., 2017, doi: 10.1016/j.compind.2017.04.002.

[5] World Economic Forum and A. T. Kearney, Insight Report: Readiness for the Future of Production Report 2018. 2018.

[6] V. E. Satya, "Strategi Indonesia Menghadapi Industri 4.0," INFO Singk. Bid. Ekon. dan Kebijak. Publik, 2018. 
[7] Kementerian Perindustrian RI, "Rencana Induk Pembangunan Industri Nasional 2015 - 2035," Rencana Induk Pembang. Ind. Nas. 2015-2035, 2015.

[8] A. Ciffolilli and A. Muscio, "Industry 4.0: national and regional comparative advantages in key enabling technologies," Eur. Plan. Stud., 2018, doi: 10.1080/09654313.2018.1529145.

[9] C. B. Frey and M. A. Osborne, "The future of employment: How susceptible are jobs to computerisation?," Technol. Forecast. Soc. Change, 2017, doi: 10.1016/j.techfore.2016.08.019.

[10] M. F. Mubarak and M. Petraite, "Industry 4.0 technologies, digital trust and technological orientation: What matters in open innovation?," Technol. Forecast. Soc. Change, 2020, doi: 10.1016/j.techfore.2020.120332.

[11] K. Schwab, "The Fourth Industrial Revolution: what it means and how to respond," World Econ. Forum, 2016.

[12] H. Leurent, F. Betti, and J. Narayan, "Fourth Industrial Revolution Beacons of Technology and Innovation in Manufacturing," World Econ. Forum, 2019.

[13] K. Aiginger and J. Vogel, "Competitiveness: from a misleading concept to a strategy supporting Beyond GDP goals," Compet. Rev., 2015, doi: 10.1108/CR-06-20150052.

[14] Statistics Times, "World GDP Ranking 2019 - StatisticsTimes.com,” 2019.

[15] BPS, "Statistik Perdagangan Luar Negeri Indonesia," BPS. 2019.

[16] A. Hidayatno, A. R. Destyanto, and C. A. Hulu, "Industry 4.0 technology implementation impact to industrial sustainable energy in Indonesia: A model conceptualization," 2019, doi: 10.1016/j.egypro.2018.11.133.

[17] Kementerian Perindustrian, “Indonesia's Fourth Industrial Revolution - Making Indonesia 4.0," Kementeri. Perindustrian, 2018.
[18] Ministry of International Trade and Industry, Industry 4WRD National Policy on Industry 4.0. 2018.

[19] U. Government, "Industrial Strategy: Building a Britain fit for the future," 2017.

[20] T. and I. METI - Ministry of Economy, "Vision of New Industrial Structure -Japan's strategies for taking the lead in the Fourth Industrial Revolution - Interim Report by New Industrial Structure Committee," METI, Japan, 2016.

\section{Biografi Penulis}

Hari Wisnu ST. IPP.

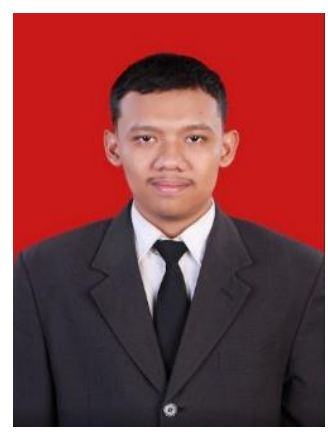

Hari Wisnu Murti, S.T., IPP Menempuh pendidikan S-1 di Departemen S-1 Teknik Kimia Universitas Diponegoro lulus pada tahun 2016 dengan gelar Sarjana Teknik (ST). Memperoleh gelar Insinyur Profesional Pratama (IPP) setelah dinyatakan lulus kualifikasi pada bulan Oktober tahun 2019. Diterima sebagai PNS di lingkungan Kementerian Perindustrian pada tahun 2018 di Pusat Penelitian dan Pengembangan Teknologi Industri dan Kekayaan Intelektual dan saat ini bertugas di satuan kerja Pusat Optimalisasi Pemanfaatan Teknologi Industri dan Kebijakan Jasa Industri.

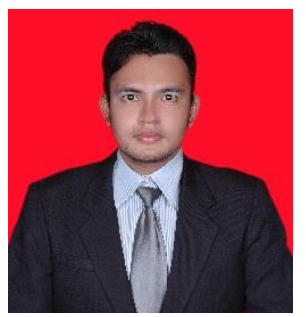

Ir. M. Tirtana Siregar S.TP. MT Menempuh Pendidikan S-1 di Universitas Padjadjaran, Fakultas Teknologi Industri Pertanian, jurusan Teknik Industri lulus pada tahun 2007 dengan gelar Sarjana Teknik Pertanian (STP). Pendidikan S2 di tempuh di Universitas Indonesia, Fakultas Teknik, jurusan Teknik lulus tahun 2013 dengan gelar Magister Teknik (MT). Saat ini sedang menempuh pendidikan S-3 di Universitas Indonesia, Fakultas Teknik, jurusan Teknik Industri dimulai pada tahun 2020. Diterima PNS di lingkungan Kementerian Perindustrian pada tahun 2015 di Politeknik APP Jakarta dan saat ini bertugas sebagai dosen program studi Manajemen Logistik Industri Elektronika 